УДК 37.091:004]:005=111

\title{
MODERN TECHNOLOGIES OF MANAGEMENT OF EDUCATIONAL ESTABLISHMENTS
}

Shvardak Mariana

\section{СУЧАСНІ ТЕХНОЛОГІЇ УПРАВЛІННЯ ЗАКЛАДАМИ ОСВІТИ}

Швардак М. В.

The article aim at determining and analysis of modern technologies of management of educational establishment. The essence and meaning of management technology is investigated, such managerial technologies are characterized "public relations», monitoring technology, personnel management, cloud technology. As a result of carried out research, it was found out that none of the existing technology in pedagogical science does not provide an optimal result of the effectiveness of management of educational establishment. It is necessary to determine such complex of technologies which takes into account the level of scientific and practical training of subjects for its realization, peculiarities of educational establishment, the level of students' educational competence, their differentiated needs in acquiring education, the level of teaching and methodological support as well as technical equipment of the educational process, requirements and needs the present time.

Keywords : managerial technology, educational establishment, the head.

Метою даної статті є визначення та аналіз сучасних технологій управління закладами освіти. Розглянуто суть та значення технологій управління, подана характеристика таких технологій управління закладами освіти як «public relations», технологія моніторингу, управління персоналом, хмарні технології. $У$ результаті проведеного дослідження з'ясовано, що жодна із існуючих в педагогічній науці $і$ практиці технологія управління окремо взята не дає оптимального результату ефективності управління закладом освіти. Необхідно визначати такий їх комплекс, який враховує ступінь науково-практичної підготовки суб'єктів до його реалізачії, особливості закладу освіти, ступінь навчальної компетентності учнів, їх диференційованих потреб у набутті освіти, рівень навчально-методичного забезпечення та технічного оснащення навчального процесу, вимог та потреб сьогодення.

Ключові слова: технологї̈ управління, заклад освіти, керівник.

Present changing world has a particular influence on Ukrainian society, which is itself being deeply transformed. Because of a glorious event for the newest history of Ukraine - Revolution of Dignity, our country, as never before, has witnessed the influence of global changes and processes. These changes are caused by the changeover of people from the industrial society, which is nowadays in deep crisis, to post-industrial or informational one.

According to this fact, Ukraine was in a difficult geopolitical situation.

The problem still remains unsolved whether our state will pass through all trials and whether it will become the part of a new world. Taking into consideration mentioned above, we are to be prepared for great transformations, first of all, in education, which will enable our state to become equal among the equal in a globally changed world.

Fist of all, the static nature of Ukrainian education despite new national and global challenges raises anxiety. Education requires radical changes, reforms and this is an axiom. The foundations of these changes have been already laid in the new standards of education. Підвалини цих змін уже закладаються в нових стандартах освіти. But, as it is known, the main thing in the post-industrial world is not the emergence of new, though progressive, laws. The document itself is worth for nothing. The implementation of these laws and their practical use is important. Thus, this very practice in most cases is changing very slowly. Point A (this is the education we have) and point $\mathrm{B}$ (the education we dream about), can be realized by a long and difficult way. The normative 
base, on this way, fulfills the function of traffic rules, while everything else - the choice of route, passengers, fuel purchase - the case of a driver, that is, the head, the manager. In order to get the right place in time without losing the "transport" and "passengers", the head should be a skilled driver, being confident in himself and in those who are close to him. New management technologies are needed in order to turn educational establishments into ones that meet the requirements of modern world.

No doubt, that the urgency of implementation of new management technologies is closely connected with state policy of national education in the context of euro integration and reforming. In this respect, innovative technologies in managerial activity of the head of educational establishment influence the quality of school education and support its positive changes.

The analysis of recent researches of this problem proved that scientists have characterized the essence and peculiarities of constructing managerial technologies in educational establishments (L.

Danylenko, Y. Konarzhevskyi, V. Pikelna), the specificity of working-out and realization of some managerial technologies is disclosed (A. Yermola, O. Liubarska, I. Pidlasyi, T. Sorochan, P. Tretiakov).

The aim of the article is to determine and analyze modern technologies in management of educational establishments.

Nowadays, technological management is a distinctive feature of the management of the educational establishment. It determines the search for those managerial tools that can be used effectively in management of an educational institution. Technologization of management facilitates its streamlining, including those works and actions of the head and worker which are not necessary in achieving the expected result of management activity, formalizes the implementation of managerial functions.

The term «managerial technology» has been included into conceptual apparatus of the science and practice of management of educational establishment thanks to the use of the method of scientific expansion. We define it as a combination of managerial influence means and methods of reaching the set goals of organization, such as [4, p.17]: principles, laws and regularities of organization and administering; methods of obtaining and processing of information; method of effective impact on workers; control and monitoring system.

We are of the opinion, that new model of management of educational establishment should be democratic, clear, state and social, it should also be based on humanity principles, initiative, free choice, responsibilityi, combination of collegiate and self-governing, individual management.

The basic criteria of modern school education have been approximation to European and world standards, openness of educational systems, new approaches to the development of national education, implementation of pedagogy of partnership and cooperation. Accordingly, changes in the management of educational institutions should be systemic and purposeful. First of all, it concerns new approaches to modern school management, new managerial technologies.

In terms of this study, we will dwell on some of the managerial technologies that are the tools for the head of the educational establishment in realizing set goals. Managerial decisions are considered to be the basis of any activity. The task of the modern manager is not only to make optimal decisions, but also to create the most favorable conditions for their implementation: to create a team of people who share the same ideas, to establish an effective system of communication of all parts of the process, to support permanent monitoring of each stage, to motivate, control, and to comply the norms of labor care, to find ways of alternative replenishment of the material and technical supply.

"Public relations" technologies are widely used in modern managerial activity. They are predominantly directed on the support of competitiveness of one or another educational establishment, as well as on creation of its positive image. There are schools, possessing strong staff potential, desire and ability to productive work but, nevertheless, lose pupils because of the fact that they couldn't depict their advantages in time. The essence of the use this technology lies in the fact that even the least positive moments, even the least vivid achievements of pupils should be paid attention to brought to the knowledge of publicity. Nowadays, Internet resources help in this respect, especially social networks, which easily share and spread necessary information [1, p.18]. 
The authority cannot do without correctly realized technology of personnel management, especially - management of teaching staff. Present situation in Ukrainian education is characterized by the gap between social status and economic status: people from rather high social level are of low economic welfare. Crisis situations influence also school staff situation. A great loss has done to stuff of educational establishment in the result of mass flow of young and prospective professionals into other spheres, the general aging of the staff, the sharp decline in the prestige of the staff. Technology of personnel management of a modern educational institution aims at: activation and qualitative transformation of the innovative ability of teachers; careful attitude towards the older generation of teachers, support for their professional activity; support of a collegiate culture for solving educational problems; ensuring transparency of the rights and obligations of all subjects of the education system, planning and control methods of their activities, clearly integrated into the cycle of education system management at any level; observance of the rights of autonomy of educational institutions in solving their personnel issues.

The quality of teaching is the basic factor, which determines the abilities of development of educational establishment. Thus, the results of teacher's work should be judged by his/her contribution into the increase of the efficiency of the use of human funds of school. Labour stimulation can be realized through gratuity, через преміï, honorary diplomas and gratitudes. It is important, to accentuate on the important contribution of every worker [3, p.42].

One more technology, which, in our opinion, is the basic for any modern school, monitoring-based technology. The use of monitoring investigation has always been of great importance, but putting into practice external independent evaluation has made it extremely important since 2015, when the results of EIE are accepted as the results of FSA. Te tasks of the authority of educational establishment is to determine the level of academic achievements of a pupil starting from primary forms to graduation. Pedagogical process must be built up on the basis of obtained results, thus, every day of attending school for a pupil could be a step ahead for a pupil. Otherwise he/she loses interest of going to school. The task of the head is to organize monitoring investigations the way, they could be objective, systemic, could reflect the real state of things and were the basis for analysis and further actions towards improving results [2, p.108].

Without exaggeration, it can be proved that within cloud technology it is possible to reduce paper routine of teachers and endless teaching-staff meetings devoted to some managerial issues. These are technologies enable Internet users to access the server's computer resources and use the software as an online service. Most cloud services have their own mobile applications to operate them easier on tablets and smartphones, allowing in such a way to have a permanent connection with all the data anywhere and anytime. The "cloud" supports the three main activities that determine certain areas of their use: communication is the process of exchanging the information (facts, ideas, views, emotions, etc.) between two or more people; Collaboration is a process of joint activity, for example in the intellectual sphere, of two or more people or organizations to achieve common goals with knowledge exchanged, reaching agreement; cooperation - collaboration, the interrelation of people in the processes of their activities.

For instance, teachers of school work out some sort of internal statute. Google-group is created «Teachers of educational and teaching complex №N» and this group is given the right to redact this statute. To stay in an educational establishment is not necessary for participants of these processes, while the opportunity to express their position and to be heard is available to all members of the team. Consequently, we are convinced that cloud technologies are irreplaceable in the management of the educational institution and have significantly simplified management activities [1, c.17].

It is worth indicating, that none of the existing in pedagogical science separately taken management technology does not provide an optimal result of the effectiveness of the management of educational establishment. It is necessary to determine their combination, taking into account the degree of scientific and practical training of subjects for its implementation, the peculiarities of the institution of education, the degree of students' educational competence, their differentiated needs in 
acquiring education, the level of teaching and methodological support and technical equipment of the educational process, requirements of the present world. At the same time, the study does not investigate all aspects of the problem and brings to the new theoretical and practical issues that require a solution in the field of educational management technologies.

\section{References}

1. Bondar O. (2010), Funktsii i tekhnolohii upravlinnia pedahohichnym personalom navchalnoho zakladu [Functions and technologies of management of educational staff of the educational institution], Shkola dlia zastupnykiv i ne tilky, No 10 (58), pp. 16-20.

2. Sorochan T.M. (2009), Suchasni tekhnolohii shkilnoho menedzhmentu: opornyi konspekt dlia slukhachiv kursiv pidvyshchennia kvalifikatsii kerivnykiv zahalnoosvitnikh navchalnykh zakladiv: Navchalnyi posibnyk [Modern technologies of school management], Luhansk, 208 p.

3. Marmaza O.I. red., (2003), Upravlinnia navchalnym zakladom: Navchalno-metodychnyi posibnyk [Management of an educational institution], Ranok, Kharkiv, 312 p.

4. Khrykov Ye. M. (2006), Upravlinnia navchalnym zakladom: Navch. posib. [Management of an educational institution], Znannia, Kyiv, 365 p.

\section{УДК 159.943:378.011.3-052}

\section{ДОСЛІДЖЕННЯ АСЕРТИВНОЇ ПОВЕДІНКИ СТУДЕНТІВ У СКЛАДНИХ ЖИТТЕВИХ СИТУАЦІЯХ}

Щербан Т. Д., Ляшин Я. С.

\section{STUDY OF STUDENT'S ASSERTIVE BEHAVIOUR IN DIFFICULT LIFE SITUATIONS}

Scherban Tetyana, Liashyn Yaroslav

Проведено дослідження асертивної поведінки студентів у складних життєвих ситуачіях сочіального характеру та, зокрема, впливу гендерного фактору на вибір асертивної поведінки як копінг-стратегії.

Ключові слова: асертивність, копінг, складна життєва ситуачія, опанування, адаптація, копінг-стратегіï, стрес.

The article deals with assertive behavior as a coping strategy.

The research goals were studying of student's assertive behavior as a coping strategy in difficult social situations and impact of gender on choice of this coping strategy.

It is stated that constructive level of assertive behaviour as a coping strategy have been shown by 48,7\% of investigated persons (57,7\% of male and 44,2\% of female).

$39,8 \%$ of investigated persons demonstrated low level of this coping strategy, among female this level of assertive behavior has been shown by 48,1\% of investigated persons.

Gender differences in behavior in difficult social situations have been found. Male have demonstrated more propensity to constructive manifestation of assertive behaviour as coping strategy, female have demonstrated more propensity to passive behavior than male and male have demonstrated more propensity to aggressive and antisocial behavior than female.

Keywords: assertivity, coping, difficult life situation, adaptation, coping strategy, stress.

В житті кожної людини є місце для складних, психологічних ситуацій. Сучасне українське суспільство переживає період серйозних змін, що особливо гостро ставить перед особистістю проблему конструктивного подолання життєвих труднощів. Протягом останніх 